\title{
The influence of floodplain morphology and river works on spatial patterns of overbank deposition
}

\section{Thonon, H. Middelkoop ${ }^{\star}$ \& M. van der Perk}

Centre for Geo-ecological Research (ICG) \& Netherlands Centre for River Studies (NCR), Departement Fysische Geografie, Faculteit Geowetenschappen, Universiteit Utrecht, Postbus 80115, 3508 TC Utrecht, the Netherlands.

* Corresponding author. Email: h.middelkoop@geo.uu.nl

Manuscript received: January 2006; accepted: February 2007

\begin{abstract}
Floodplain topography and related hydraulic patterns of overbank flow constitute a major control on the amounts and patterns of sediment deposition on floodplains. We studied the differences in sediment deposition at two scales along two river branches of the lower River Rhine in the Netherlands: the Waal and IJssel River. Human alterations like levelling and embankment construction have severely impacted the floodplains along the Waal River branch (average discharge: $1500 \mathrm{~m}^{3} \cdot \mathrm{s}^{-1}$ ), whereas the relatively wide floodplains along the IJssel River (average discharge: $250 \mathrm{~m}^{3} \cdot \mathrm{s}^{-1}$ ) still exhibit their characteristic ridge-and-swale topography and natural levees. We found that, in general, the amounts of sediment deposited sediment decreases with increasing distance to the sediment source. Clay and organic matter content generally increase with decreasing floodplain elevation. These trends are, however, far less pronounced in the Waal River floodplains than in the IJssel River floodplains. Sediment deposited on the IJssel River floodplains also contains significantly more sand than the sediment deposited on the Waal River floodplains, probably because of the absence of minor embankments along the IJssel River and its higher sinuosity. Furthermore, during inundation the individual Waal River floodplains receive more sediment per unit area than the IJssel River floodplains. At the scale of the river branch, however, the conveyance losses in the Waal River are less than in the IJssel River, because of the larger surface area of the floodplains along the IJssel River relative to its water and sediment discharge during flood events. This discrepancy stresses that both the individual floodplain sections and the total river branch should be taken into account when studying the role of overbank deposition as part of a river's sediment budget.
\end{abstract}

Keywords: human impact, floodplain topography, River Rhine, sedimentation, spatial variability, the Netherlands

\section{Introduction}

Floodplain deposition is an important process in the storage and cycling of sediments, nutrients and contaminants in river basins (e.g., Mertes, 1994; Gomez et al., 1997; Middelkoop \& Asselman, 1998; Walling, 1999; Thoms et al., 2000; Nanson \& Croke, 2002; Walling \& 0wens, 2003). The patterns, amounts and characteristics of floodplain sedimentation have been studied extensively (e.g., Marriott, 1992; Guccione, 1993; He \& Walling, 1997, 1998; Simm \& Walling, 1998; Walling \& He, 1998; Walling et al., 1998; Lecce \& Pavlowsky, 2004; Walling et al., 2004). With respect to the sediment-associated contaminants, especially deposition of heavy metals received attention of numerous authors (e.g., Leenaers \& Rang, 1989; Lecce \&
Pavlowsky, 1997; Hudson-Edwards et al., 1999; Middelkoop, 2000; Hren et al., 2001). Most studies on variability in overbank deposition focused on small streams (e.g., Lambert \& Walling, 1987; Simm \& Walling, 1998; Walling \& He, 1998; Walling et al., 2004), concerned historical floodplain deposits (e.g., Taylor, 1996; Lecce \& Pavlowsky, 1997, 2004) or used modelling (e.g., Nicholas \& Walling, 1997; Sweet et al., 2003; Van der Lee et al., 2004). Studies of contemporary overbank deposition of sediment on large river floodplains (Kesel et al., 1974; Mertes, 1994; Middelkoop \& Asselman, 1998; Middelkoop, 2000) related to high-magnitude/low-frequency events are however relatively scarce (Walling et al., 1998). Yet, empirical studies on contemporary sediment deposition are still needed to gain insight in the key variables that determine spatial 
variability of floodplain deposition (Walling et al., 2004) and for calibration and validation of floodplain deposition models (Gomez et al., 1997; Lecce \& Pavlowsky, 2004).

In general, variability in overbank deposition of sediment is determined by factors that operate at two scales: at the scale of the river branch and the individual floodplain section. Channel morphology, floodplain width, sediment load and discharge regime determine most of the variability in floodplain deposition between river branches (Lecce, 1997; Foster et al., 2002; Sweet et al., 2003; Lecce \& Pavlowsky, 2004). Variation in hydraulic patterns of overbank flow and local topography form the main source of variability in deposition within and between floodplains (Lambert \& Walling, 1987; Nicholas \& Walling, 1997; Lecce \& Pavlowsky, 2004). Although these two groups of factors play a considerably different role at different spatial levels and lead to different spatial patterns in sediment deposition, only some authors have directly compared the spatial variation in floodplain deposition at these two scales (e.g., Foster et al., 2002; Sweet et al., 2003). The aim of this study is therefore:

- to describe the variation in both sediment characteristics and spatial distribution of overbank deposition within and between individual floodplain sections and between river branches of a large river;

- to relate this spatial variation to the topographical and hydrological factors that govern overbank deposition at the scales of the individual floodplain sections and the river branches.

We compared embanked floodplains along two distributaries of the lower River Rhine: the heavily influenced floodplains along Waal River, exhibiting artificial levees and levelled floodplains, and the less disturbed IJssel River floodplains, with natural levees and a classical ridge-and-swale floodplain topography. We obtained sediment trap data for seven floodplains and five inundation events. From the sediment samples we determined amounts of sediment deposition, grain-size characteristics and organic matter content. For each trap location we determined the duration of sediment conveyance, distance to the river channel and elevation. We combined these data to hypothesise the possible sources of variation and subsequently used statistics to test these hypotheses at the scale of both the distributary and individual floodplain section.

\section{Study area}

The River Rhine basin is located in North-western Europe and measures approximately $185,000 \mathrm{~km}^{2}$. The river is about $1320 \mathrm{~km}$ in length and has a mean discharge of about $2250 \mathrm{~m}^{3} \cdot \mathrm{s}^{-1}$ at the Dutch-German border. Currently, the River Rhine transports about $3 \cdot 10^{9} \mathrm{~kg}$ of suspended sediment per year (Asselman et al., 2003; Thonon, 2006). Downstream of the Dutch-German border, the River Rhine divides into the Waal River and the Pannerdens Canal (Fig. 1). The Pannerdens Canal subsequently splits into the Nederrijn River and the IJssel River. The Waal River discharges two-third of the River Rhine discharge $\left(1500 \mathrm{~m}^{3} \cdot \mathrm{s}^{-1}\right.$ on average), the Nederrijn River two-ninth $\left(500 \mathrm{~m}^{3} \cdot \mathrm{s}^{-1}\right)$ and the IJssel River the remaining one-ninth $\left(250 \mathrm{~m}^{3} \cdot \mathrm{s}^{-1}\right)$.

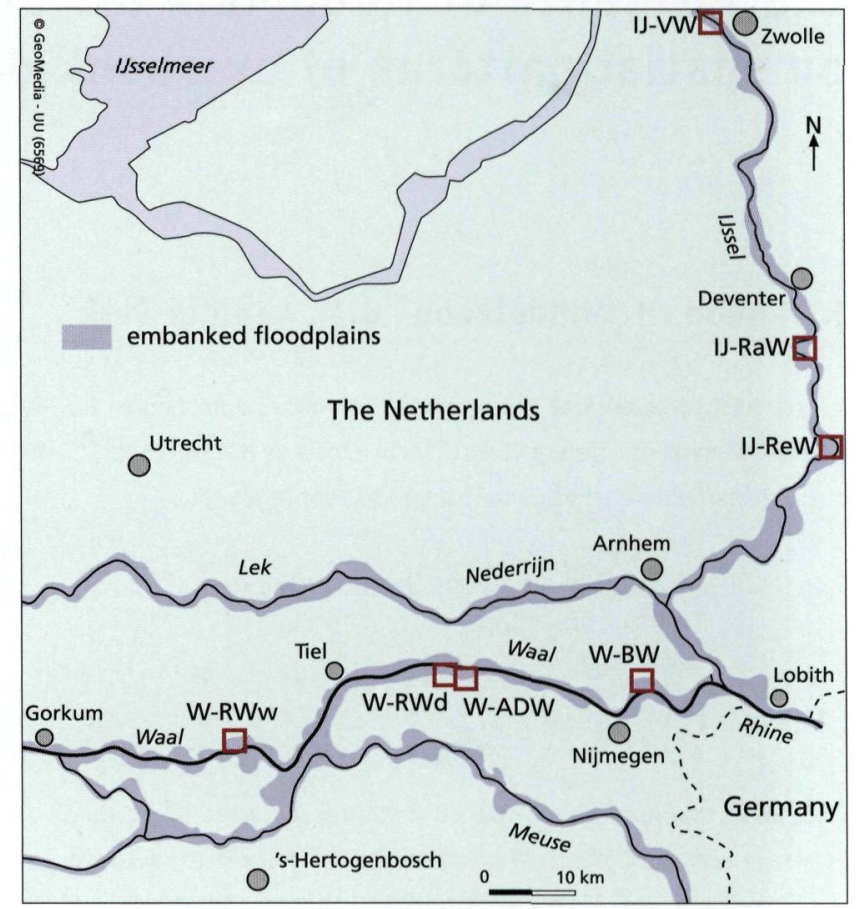

Fig. 1. Locations of the studied river branches and floodplains. See Table 1 for explanation of codes for floodplains.

Both the Waal and IJssel River branches have been embanked and harnessed by groynes. The major embankments serve as flood defence for low-lying areas close to the river. The groynes ensure that no meandering takes place and that the river channel remains deep enough for shipping. Still, the two river branches exhibit differences that influence overbank deposition (Table 1, Fig. 2). The Waal River's floodplains are three to four times as wide as the river channel (Table 1) and are located between high minor embankments (Bemmelsche Waard or W-BW floodplain and Afferdensche \& Deestsche Waarden or W-ADW floodplain) or pronounced natural levees (Rijswaard at Waardenburg or W-RWw floodplain). Between these flood-protecting features and the floodplain there is often a narrow foreshore area that does not belong to the floodplain (Fig. 2). The minor embankments and natural levees protect the floodplains from being inundated by low-magnitude peak discharges. The Rijswaard at Druten or W-RWd floodplain is an exception for the Waal River: it is not protected from low-magnitude flooding (Fig. 2). The IJssel River, by contrast, is often only (partly) bordered by less pronounced natural levees. Two distinct features from IJssel floodplains are their relatively large widths (floodplain/channel width ratios around 10, Table 1) and the characteristic ridge-and-swale morphology. The Ravenswaarden (IJ-RaW) and Reuversweerd (IJ-ReW) and to a lesser extent the Vreugderijker Waard (IJ-VW) floodplains 
Table 1. The floodplains studied, their codes, type of protection against low-magnitude flooding, discharge at which they are inundated, surface area and their floodplain/channel width ratio.

\begin{tabular}{|c|c|c|c|c|c|c|}
\hline River branch & Code & Floodplain name (in Dutch) & Protection & $Q_{\text {inund }}{ }^{1}\left(m^{3} \cdot s^{-1}\right)$ & Size $\left(\mathrm{km}^{2}\right)$ & F/C ratio ${ }^{2}$ \\
\hline \multirow[t]{4}{*}{ Waal River } & W-BW & Bemmelsche Waard & High minor embankment & 6500 & 4 & 4 \\
\hline & W-ADW & Afferdensche \& Deestsche Waarden & High minor embankment & 6300 & 3 & 3 \\
\hline & W-RWd & Rijswaard at Druten & None & $>3500$ & 0.5 & 1 \\
\hline & W-RWw & Rijswaard at Waardenburg & High natural levee & $>5000$ & 3.5 & 3 \\
\hline \multirow[t]{3}{*}{ IJssel River } & IJ-ReW & Reuverswaard & Natural levee (partly) & $>3000$ & 3 & 9 \\
\hline & IJ-RaW & Ravenswaarden & Natural levee (partly) & $>3000$ & 2.5 & 14 \\
\hline & IJ-VW & Vreugderijker Waard & Natural levee (partly) & $>5000$ & 1.5 & 3.5 \\
\hline
\end{tabular}

1 The discharge at which the river inundates the floodplain $\left(\mathrm{Q}_{\text {inund }}\right)$ is given for the Dutch-German border. A $>$ ('larger than') sign indicates that the river only partly inundate the floodplain at that discharge.

2 The maximum floodplain width/channel width ratio.
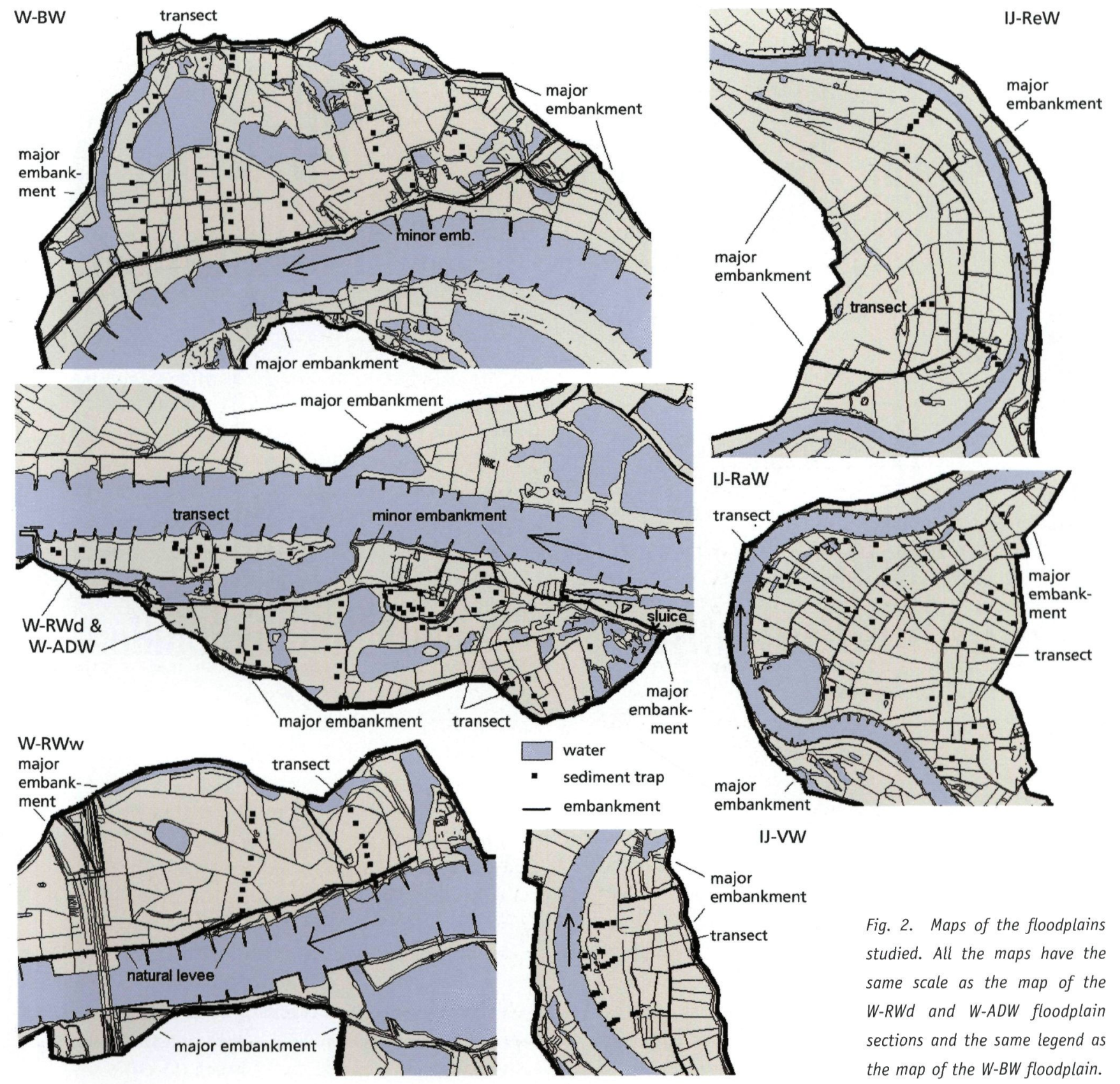

major

embankment 
are examples of these features (Table 1, Fig. 2). Land use in all floodplains is mainly pasture with some floodplain forest, shrub-, reed- and marshland. Arable land is only present in the W-BW and W-ADW floodplains.

\section{Materials and methods}

\section{Sampling and analytical techniques}

Figure 3 shows the hydrographs and sedigraphs and Table 2 shows the characteristics of the inundations for which we deployed sediment traps. We gathered the data for the W-ADW and W-RWd in cooperation with Wijnhoven et al. (2006) and
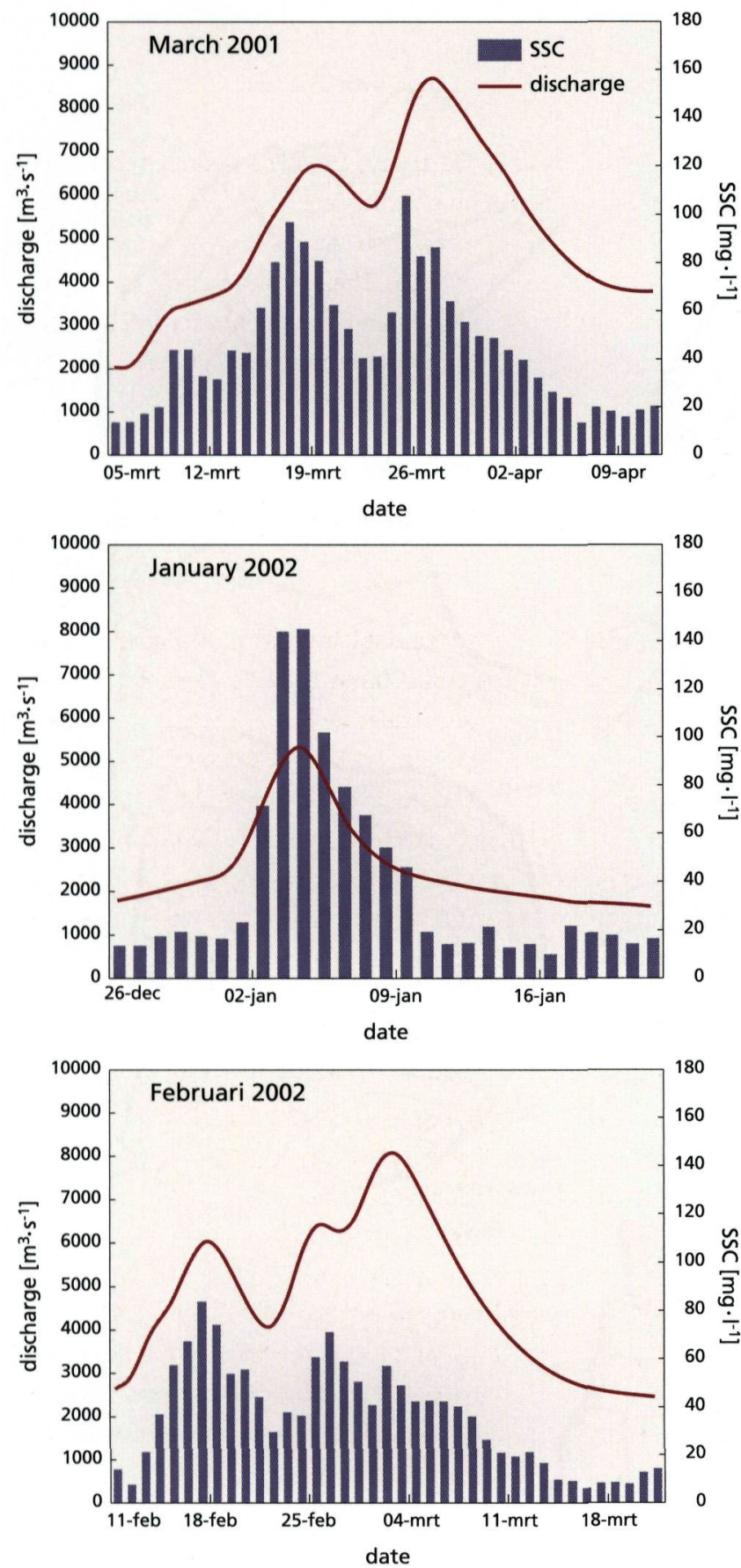

for the W-RWw, IJ-ReW and IJ-VW floodplains with Maas et al. (2003). This cooperation explains the somewhat different sampling designs for the different floodplains (Fig. 2), with a stratified random sampling in the W-ADW and W-RWd floodplains, few transects in the W-RWW, IJ-ReW and IJ-VW and transects covering the whole floodplain in the W-BW and IJ-RaW floodplains. All studies nevertheless applied the same traps as used by Asselman \& Middelkoop (1998). These traps have a pliable base of $50 \times 50 \mathrm{~cm}$ with artificial grass tufts of $2 \mathrm{~cm}$. We placed them in the floodplains in advance of an inundation, using five stainless steel pins to attach them to the floodplain soil. After recession of the floodwater, we gathered all sediment traps and transported them to the laboratory in
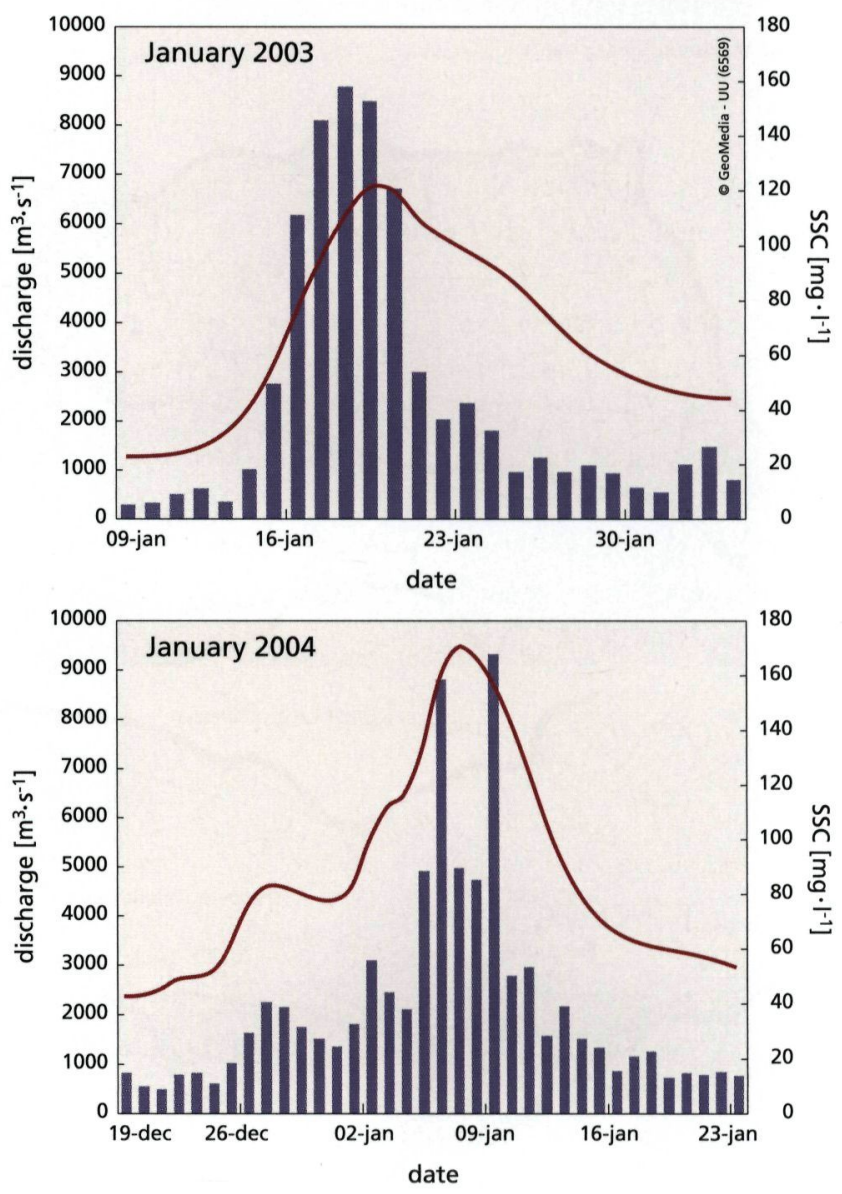

Fig. 3. Discharge curves for the five sampled peak discharges at gauging station at the Dutch-German border (Lobith, the Netherlands). Data source: V\&W (2005). 
Table 2. Number of observations, period when the observations were done, peak discharge and suspended sediment concentration of the studied events, duration of the event and supply of suspended sediment (see also Fig. 2).

\begin{tabular}{|c|c|c|c|c|c|c|}
\hline Floodplain & n of traps & Inundation period & $a_{\text {peak }}^{1}\left(m^{3} \cdot s^{-1}\right)$ & $\mathrm{SSC}_{\text {peak }}{ }^{1,2}\left(\mathrm{mg} \cdot \mathrm{l}^{-1}\right)$ & Inundation duration $^{3}$ & Sediment supply duration ${ }^{3}$ \\
\hline W-BW & 46 & Jan. 2003 & 9372 & 107 & 11.3 & 6.0 \\
\hline W-ADW & 41 & Feb. 2002 & 7958 & 57 & 10.0 & 5.2 \\
\hline W-RWd & 21 & Jan. 2002 & 5250 & 130 & 6.5 & 6.5 \\
\hline W-RWw & 17 & Mar. 2001 & 8664 & 79 & 10.2 & 4.4 \\
\hline IJ-ReW & 25 & Mar. 2001 & 8664 & 79 & 29.6 & 17.7 \\
\hline IJ-RaW & 56 & Jan. 2004 & 6632 & 90 & 21.9 & 18.9 \\
\hline IJ-VW & 20 & Mar. 2001 & 8664 & 79 & 25.4 & 25.4 \\
\hline Total & 226 & $2001-2004$ & & & 15.5 & 11.3 \\
\hline
\end{tabular}

1 Source: V\&W (2005).

$2 \mathrm{SSC}_{\text {peak }}=$ suspended sediment concentration at peak of discharge event.

3 Average values in days for sediment traps. Sediment supply duration is the average time during which sediment could settle on a trap.

plastic bags. We retrieved the sediment from the traps using a high-pressure cleaner. After drying at $105^{\circ} \mathrm{C}$ we weighed each sample and calculated the deposition amounts $\left(\mathrm{g} \cdot \mathrm{m}^{-2}\right)$.

From the retained soil we determined organic matter (OM) content by loss on ignition. Dispersed grain size was analyzed with the Coulter LS 230 after removal of carbonate and organic matter. We considered median grain size $\left(d_{50}\right)$, clay $(0-2 \mu \mathrm{m})$, fine silt $(2-16 \mu \mathrm{m})$, coarse silt $(16-63 \mu \mathrm{m})$ and sand (63 $2000 \mu \mathrm{m})$ percentage. Following Brown (1985), we discriminated between sandy levee deposits with $d_{50}>63 \mu \mathrm{m}$ and overbank deposits with $d_{50}<63 \mu \mathrm{m}$ and only studied the latter.

\section{Hydrological and topographical data}

Elevation above sea level for every sediment trap was derived from the Actual Height model of the Netherlands (AHN, Adviesdienst Geo-informatie \& ICT, Rijkswaterstaat, Delft, the Netherlands), which is a digital elevation model with a resolution of $5 \times 5$ meter based on laser altimetry data. Relative floodplain elevation was calculated by subtracting the absolute elevation by the mean summer water level in the river channel.

We calculated the inundation period for every trap by analysing the location and elevation of the trap and water levels measured at the nearest measurement station (V\&W, 2005). In case the trap was behind a natural levee, minor embankment or other obstacle, we assumed this first had to be overtopped before inundation of the trap could occur. Then, we counted for each trap the time it was under water. We assumed that drainage of the floodwater directly followed the falling stage in the river channel. In floodplains with a minor embankment drainage proceeded via a sluice. To obtain the (potential) duration of sediment conveyance, we counted the time during which the water level in the river channel was higher than the top of the minor embankment or natural levee. Only in this situation transfer of sediment from the channel to the floodplain may take place.
For statistical tests we always used the default tests in the statistical package SPSS, i.e., a Students' t test (for two samples) or ANOVA (for more than two samples) with a one-sided significance level $(\alpha)$ of 0.05 . These tests can be used if the sample size is larger than 30 and the population distribution is expected to be normal, which was always the case.

\section{Results}

\section{Variation between river branches and floodplain sections}

Table 3 gives the grain size data for the floodplains studied. During the five events from March 2001 to January 2004, an average of $1.1 \mathrm{~kg} \cdot \mathrm{m}^{-2}$ of sediment was deposited on the floodplains studied. The Waal River floodplains receive significantly more sediment per unit area than the IJssel River floodplains $(p=0.001)$. Furthermore, the amounts of sediment deposition in the IJssel River floodplains are significantly different from each other $(p=0.000)$, indicating a downstream trend, with less sedimentation occurring farther downstream (Table 3 ). The Waal River does neither exhibit these significant differences $(p=0.070)$ nor such a downstream trend.

A typical floodplain deposit contained $22 \%$ clay, $47 \%$ fine silt, $21 \%$ coarse silt, $10 \%$ sand and $14 \%$ organic matter. These values are similar to values for Waal and Meuse River floodplains reported by Asselman \& Middelkoop (1998) for major floods in 1995 and 1993. The Waal River floodplain deposits, by contrast, only contain a few percent sand and have a $d_{50}$ of around $7 \mu \mathrm{m}$. Although the $\mathrm{W}-\mathrm{RWw}$ clearly is an exception with $19 \%$ sand and a $d_{50}$ of $17 \mu \mathrm{m}$, the Waal River floodplain deposits are significantly finer than those along the IJssel River $(p=0.000)$. The IJ-RaW floodplain deposits are significantly richer $(p=0.001)$ in organic matter $(20 \%)$ than other floodplains (14\%). Data from V\&W (2005) nevertheless indicate that the percentage of organic matter in the suspended matter during 
Table 3. Amount of sediment deposition and sediment characteristics (sand, clay and organic matter content and median grain size) for the deposited sediments in the floodplains studied (Fig. 2).

\begin{tabular}{|c|c|c|c|c|c|c|c|c|c|c|c|c|c|c|c|}
\hline \multirow{2}{*}{$\begin{array}{l}\text { Variable } \\
\text { Statistic }\end{array}$} & \multicolumn{3}{|c|}{ Sed. dep. $\left(\mathrm{g} \cdot \mathrm{m}^{-2}\right)$} & \multicolumn{3}{|c|}{ Clay content (\%) } & \multicolumn{3}{|c|}{ Sand content $(\%)$} & \multicolumn{3}{|c|}{ OM content (\%) } & \multicolumn{3}{|c|}{$d_{50}(\mu \mathrm{m})$} \\
\hline & Range & $\bar{x}$ & $s$ & Range & $\bar{x}$ & $s$ & Range & $\bar{x}$ & $s$ & Range & $\bar{x}$ & $s$ & Range & $\bar{x}$ & $s$ \\
\hline W-BW & $430-3730$ & 1538 & 946 & $16-36$ & 24 & 3.4 & $0-16$ & 2 & 4.0 & $8-19$ & 12 & 1.9 & $3-14$ & 6 & 2.1 \\
\hline W-ADW & $297-3461$ & 1661 & 840 & $12-30$ & 25 & 4.0 & $0-36$ & 4 & 7.6 & $8-21$ & 14 & 2.8 & $4-48$ & 8 & 8.4 \\
\hline W-RWd & $336-3286$ & 1037 & 715 & $13-31$ & 26 & 4.1 & $0-29$ & 2 & 6.3 & $10-20$ & 15 & 2.7 & $5-29$ & 7 & 5.2 \\
\hline W-RWw & $217-3812$ & 1439 & 972 & $11-27$ & 18 & 4.3 & $1-48$ & 19 & 13 & $4-18$ & 10 & 3.7 & $5-62$ & 17 & 15 \\
\hline Waal & $217-3812$ & 1348 & 924 & $11-36$ & 24 & 4.8 & $0-48$ & 7.3 & 11 & $4-21$ & 13 & 3.1 & $3-48$ & 8.7 & 8.6 \\
\hline IJ-ReW & $376-2849$ & 1503 & 804 & $8-28$ & 21 & 5.0 & $1-53$ & 14 & 14 & $4-17$ & 11 & 2.9 & $5-63$ & 13 & 14 \\
\hline IJ-RaW & 173-1989 & 762 & 438 & $10-26$ & 20 & 4.1 & $3-45$ & 15 & 11 & $7-29$ & 20 & 4.7 & $5-45$ & 11 & 7.5 \\
\hline IJ-VW & $67-1401$ & 438 & 377 & $11-26$ & 19 & 4.9 & $5-49$ & 22 & 14 & $5-23$ & 12 & 4.5 & $6-61$ & 17 & 17 \\
\hline IJssel & $67-2849$ & 881 & 657 & $8-28$ & 20 & 4.5 & $1-53$ & 16 & 13 & $4-29$ & 16 & 6.1 & $5-63$ & 12 & 12 \\
\hline Total dataset & $67-3812$ & 1144 & 847 & $8-36$ & 22 & 5.0 & $0-49$ & 10 & 13 & $4-29$ & 14 & 5.0 & $3-63$ & 10 & 10 \\
\hline
\end{tabular}

the inundation of January 2004 (Fig. 3) was only at an average level of 5 to $6 \%$. This may indicate that most organic matter in the IJ-RaW floodplain developed in the floodwater, for example as algae growth.

\section{Variation within floodplain sections}

Figure 4 gives the cross-sections for the most characteristic transect of every studied floodplain (see Fig. 2 for the location of the transects) for the floodplain topography, sedimentation amount, the clay and organic matter content of the deposited sediments. Note that we included data on the sandy levee deposits in Fig. 4 only to indicate where the natural levees are more or less located.

Figure 4 shows there are a number of spatial trends in the characteristics of the overbank deposits. Firstly, it appears that sediment deposition decreases with increasing distance to the river. This confirms Walling \& He (1998) and Middelkoop \& Asselman (1998). There are two clear exceptions to this trend. The first is the W-RWd floodplain, where the opposite trend is visible (Fig. 4). This is because the secondary channel in its south acts as a major sediment source (Fig. 2). The second exception is the W-ADW floodplain. This floodplain does not seem to exhibit a decrease in sedimentation amount with distance to the river. The trend seems to be stronger in the IJssel than in the Waal River floodplains. For instance, in the W-BW floodplain the amount of sediment deposition declines by one third over a distance of approximately 600 meter, whereas in the IJ-ReW and IJ-RaW this decline already takes place within 200 meter.

A second trend is the increase of the amount of sedimentation deposition and the clay content with decreasing floodplain elevation. This trend was also noted by for example Walling \& He (1998) and Lecce \& Pavlowsky (2001) for smaller streams. The only exception is the relation between sedimentation amount and elevation for the W-RWw floodplain, having an increasing amount of sedimentation with increasing floodplain elevation (Fig. 4). This may however be influenced by the decreasing distance to the river (Fig. 4). Because of the larger topographical differences, again the trend seems to be more pronounced in the IJssel River floodplains than in the Waal River floodplains.

\section{Discussion}

\section{Variation in deposition between river branches and floodplain sections}

\section{Variation in amount of sediment deposition}

The Waal River floodplains receive significantly more sediment per unit area per event than the IJssel River floodplains. However, although we measured sedimentation within the same lowland river system, we still measured during different peak discharges, which differed in suspended matter concentrations and duration (Fig. 3). Calculating the apparent settling velocity $\left(\omega_{s, a}\right)$ corrects for these flood-dependent variables and reflects the general deposition rate for a floodplain:

$$
\omega_{S, a}=S /(S S C \cdot T)
$$

with $\omega_{\mathrm{s}, \mathrm{a}}=$ apparent settling velocity $\left(\mathrm{m} \cdot \mathrm{s}^{-1}\right), S=$ sedimentation amount $\left(\mathrm{g} \cdot \mathrm{m}^{-2}\right)$ (Table 3$), S S C=$ average suspended sediment concentration during the period of sediment conveyance over the floodplain (Fig. 3) $\left(\mathrm{mg} \cdot \mathrm{l}^{-1}\right)$ and $\mathrm{T}=$ duration of sediment conveyance (s) (Table 2).

The median values for the apparent settling velocity for the floodplains vary between $2.1 \cdot 10^{-6}(\mathrm{IJ}-\mathrm{VW})$ and $6.8 \cdot 10^{-5} \mathrm{~m} \cdot \mathrm{s}^{-1}$ (W-ADW) (Fig. 5). These values are rather small compared to values for real flocs reported by Droppo et al. $(1997,2000)$. Droppo (2003) states that flocs normally settle with velocities ranging from 1 to $2.5 \cdot 10^{-3} \mathrm{~m} \cdot \mathrm{s}^{-1}$. Those values are however valid 

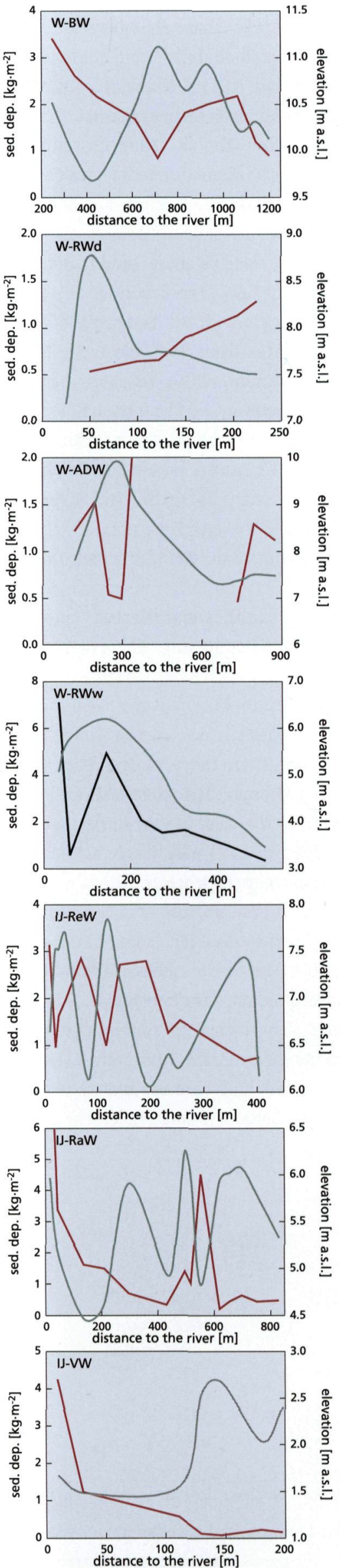
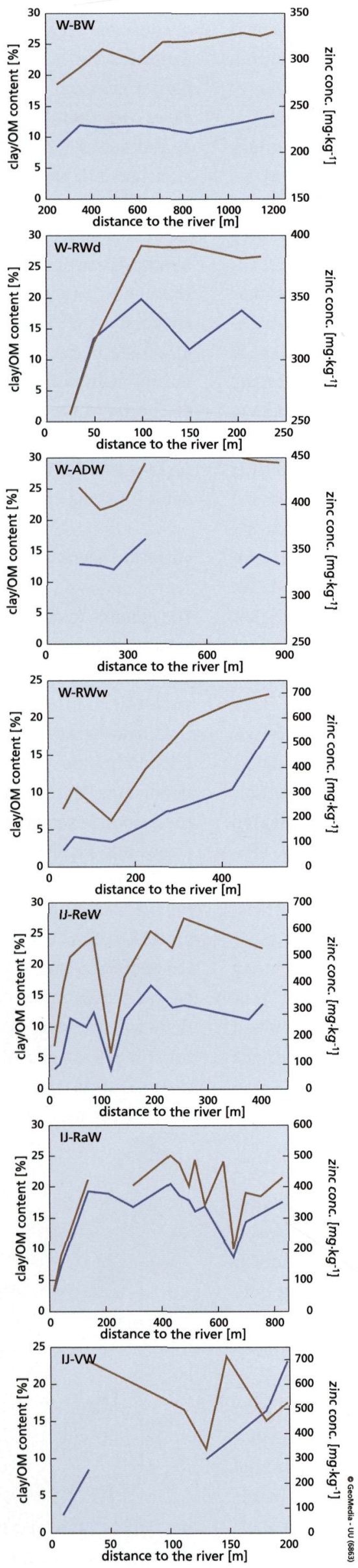

floodplain topography

- sediment deposition

- clay content

OM content

Fig. 4. Cross-sections for the seven floodplains along the transects indicated in Fig. 2, with floodplain elevation and amount of sediment deposition on the left and clay, organic matter and zinc content on the right. Note the sandy levee deposit on the W-RWd transect was $32 \mathrm{~kg} \cdot \mathrm{m}^{-2}$ and on the W-RaW transect $35 \mathrm{~kg} \cdot \mathrm{m}^{-2}$. Both sedimentation amounts were therefore not depicted. 
for individual flocs. Our values indicate how much sediment is deposited given the amount and time available for deposition. In other words, the $\omega_{s, a}$ reported here gives an indication of the trapping efficiency for a floodplain.

The Waal River floodplains have a significantly higher $\omega_{\mathrm{s}, \mathrm{a}}$ $\left(4.2 \cdot 10^{-5} \mathrm{~m} \cdot \mathrm{s}^{-1}\right.$ on average) than the IJssel River $\left(7.9 \cdot 10^{-6} \mathrm{~m} \cdot \mathrm{s}^{-1}\right.$ on average $)(p=0.000)$. This may be attributed to the minor embankments of the Waal River floodplains, which favour quiescent flow conditions in large parts of the floodplains. For instance, the W-ADW and W-BW floodplains experience flow velocities of close to $0 \mathrm{~m} \cdot \mathrm{s}^{-1}$ at $7000 \mathrm{~m}^{3} \cdot \mathrm{s}^{-1}$ at the DutchGerman border and less than $0.15 \mathrm{~m} \cdot \mathrm{s}^{-1}$ for at least $75 \%$ of their area at a discharge of $8000 \mathrm{~m}^{3} \cdot \mathrm{s}^{-1}$ (Institute for Inland Water Management and Waste Water Treatment/RIZA, Arnhem, the Netherlands, unpublished WAQUA model results). The IJssel River floodplains lack these minor embankments. This results in larger flow velocities over these floodplains: the IJ-VW and IJ-RaW floodplains both have flow velocities of $>0.15 \mathrm{~m} \cdot \mathrm{s}^{-1}$ for approximately half their floodplain areas at a discharge of $7000 \mathrm{~m}^{3} \cdot \mathrm{s}^{-1}$ at the Dutch-German border (RIZA, unpubl. data). At that discharge, the IJ-ReW floodplain experiences such flow velocities at about a third of its area (RIZA, unpubl. data). At a discharge of $8000 \mathrm{~m}^{3} \cdot \mathrm{s}^{-1}$ at the Dutch-German border, the parts with flow velocities over $0.15 \mathrm{~m} \cdot \mathrm{s}^{-1}$ increase to about three quarter, two third and half of the area for the IJ-VW, IJ-RaW and IJ-ReW floodplain, respectively (RIZA, unpubl. data). Since a large part of the sediment cannot settle at higher flow velocities, such velocities result in a lower $\omega_{s, a}$ or trapping efficiency in the individual IJssel River floodplains. The confined Waal River floodplains with their quiescent floodwater conditions, by contrast, act as efficient sediment traps. Thonon et al. (2005) also showed this discrepancy using sediment settling data. For the W-ADW floodplain, they calculated that the actual sedimentation represented $57 \%$ of the potential sedimentation flux, whereas this was only $8 \%$ in the Spankerensche Waard, an IJssel River floodplain without protection against low-magnitude flooding.

\section{Variation in grain size}

The deposits on the Waal River floodplains are significantly finer than on the IJssel River floodplains. There seem to be two topographical and morphological reasons for this phenomenon. Firstly, the minor embankments along the Waal River not only reduce the transfer of momentum from the river to the floodplain water, they also hamper the inflow of sandy material in the lower part of the water column (Middelkoop \& Asselman, 1998). Because the natural levees of the IJssel River are lower, more sand can enter the floodplains along this river branch:

Secondly, the Waal River has a lower sinuosity than the strongly meandering IJssel River (Figs 3.1 and 3.2). Bathurst et al. (2002) found that transfer of sandy sediment (in their flume experiment having a $d_{50}$ of $100 \mathrm{~mm}$ ) only took place in a confined strip along a straight channel, whereas it was deposited further away on the floodplain along their meandering channel. They attributed this to stronger convective flows over the floodplains of the meandering channel. Hudson \& Heitmuller (2003) found that the distance of sediment transfer onto the floodplain was larger for more pronounced meanders because of increased flow competence. Furthermore, the IJssel River floodplains are in general located on inner bends. These inner bends may receive more sandy sediment than outer bends due to helical flow (Ten Brinke et al., 1998; Bathurst et al., 2002). In addition, direct transport of sand may take place when river water flows over the inner bends during peak discharges (Ten Brinke, 2004). In short, because of the more pronounced meandering of the IJssel River and the absence of minor embankments, sand may be transferred further into its floodplains. This results in sandier floodplain deposits along the IJssel River than along the Waal River.

\section{Variation in downstream trend in sediment deposition}

The IJssel River manifests significant different apparent settling velocities (Fig. 5) for its floodplains, whereas the Waal River does not. In addition, the IJssel River exhibits a downstream trend in sediment deposition. Both features seem to have the same background. Conveyance losses of the IJssel River floodplains are clearly higher than those of the Waal River floodplains (Asselman \& Van Wijngaarden, 2002). Retention of the suspended matter entering the river branch during a highmagnitude flood $\left(7000-9000 \mathrm{~m}^{3} \cdot \mathrm{s}^{-1}\right)$ may reach $93 \%$ on the floodplains of the IJssel River branch, whereas this is only $8 \%$ for the total Waal River branch (Van der Lee et al., 2004). The individual Waal River floodplains may trap more than half of the sediment that enters because of the quiescent conditions behind their minor embankments (Thonon et al., 2005). However, the river branch also transports approximately six times more suspended sediment than the IJssel River. Hence, the relative loss of sediment for the total river branch is small and downstream exhaustion is hardly noticeable. The IJssel

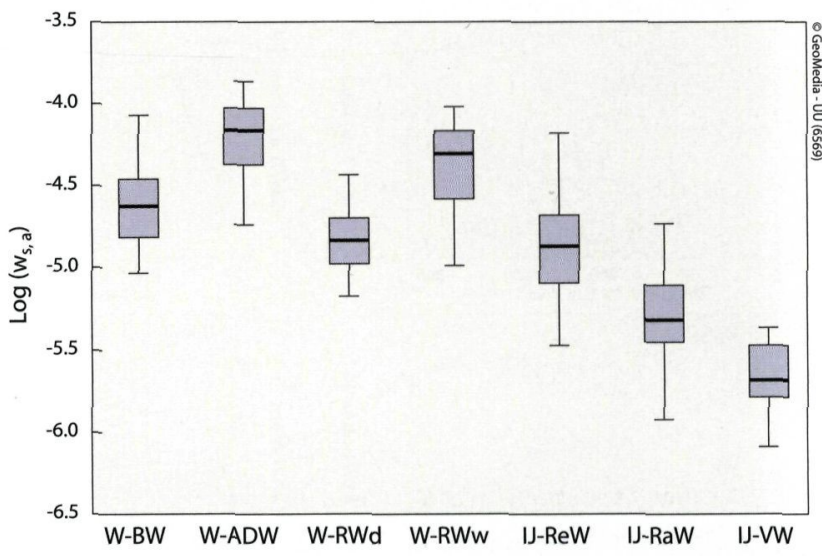

Fig. 5. Apparent settling velocity $\left(\omega_{s, a}\right)$ for all floodplains. The apparent settling velocity is a proxy for the trapping efficiency of a floodplain. 
River, on the contrary, conveys little sediment and water over its wide floodplains ( $\mathrm{F} / \mathrm{C}$ ratio in Table 1). Although the individual floodplains may trap little conveyed sediment (Thonon et al., 2005), their total surface along the river branch relative to the amount of transported sediment is considerable. This results in high trapping efficiencies at the level of the river branch (Van der Lee et al., 2004), which subsequently lead to a downstream exhaustion of suspended matter.

\section{Variation in deposition characteristics within floodplain sections}

\section{Relation between sedimentation and distance to the river}

For floodplains without artificial flood protection, sedimentation amounts tend to decrease exponentially with increasing distance to the river (see relations for the IJssel River floodplains in Fig. 6). This is because at locations further away from the sediment source (usually the river channel), less sediment is available for deposition because of exhaustion of suspended matter. In addition, sediment conveyance to locations farther away from the river channels is limited due to lower flow velocities. However, a floodplain with a secondary source of sediment, such as the W-RWd floodplain, does not feature this trend. Apparently, the secondary channel is a more important source of sediment than the river channel (see also Fig. 4). Moreover, in the W-ADW floodplain, the sedimentation amount increases with increasing distance to the river $\left(\mathrm{r}^{2}=0.27\right.$, $\mathrm{p}=0.017$ ). This may be explained by the inundation pattern: the river water first enters the floodplain in the northeast through a sluice, thereby inundating the lower distal parts of the floodplain in the southeast (Fig. 2). Only when the minor embankment is overtopped, the river water also inundates the higher parts closer to the minor embankment. The cases of the W-RWd and W-ADW floodplains show that it may be better to speak of 'distance to the sediment source' than the common denomination 'distance to the river'.

The other floodplains with minor embankments do not exhibit a significant (W-RWw floodplain, Fig. 6) or only a weak (W-BW floodplain, $\mathrm{r}^{2}=0.12, \mathrm{p}=0.016$ ) decrease in sedimentation amount with increasing distance to the river. We have already noted that minor embankments and natural levees inhibit the entrance of sandy sediment (Middelkoop \& Asselman, 1998). The input of sand is mainly important close to the river channel, yet hardly takes place within the confinement of the floodplains. Consequently, differences between closer and distal parts of floodplains behind minor embankments are smaller. This leads to low or even insignificant relations between sedimentation amount and distance to the river. Furthermore, because minor embankments also control hydrodynamics during flooding, little variation in flow velocity and inundation duration takes place, leading to relatively homogeneous sediment deposits behind flood protection works (Wyżga, 1999).

\section{Relation between sedimentation and floodplain elevation}

All three IJssel River floodplains and the W-ADW $\left(\mathrm{r}^{2}=0.20\right.$, $\mathrm{p}=0.003$ ) and W-RWd floodplain show a significant decrease in sedimentation amount with increasing floodplain elevation (Fig. 7), but the W-BW (Fig. 7) and W-RWw $\left(\mathrm{r}^{2}=0.01, \mathrm{p}=0.65\right)$
Fig. 6. Relation between distance to the river and sediment deposition for the $W$-RWW floodplain and the three IJssel River floodplains.
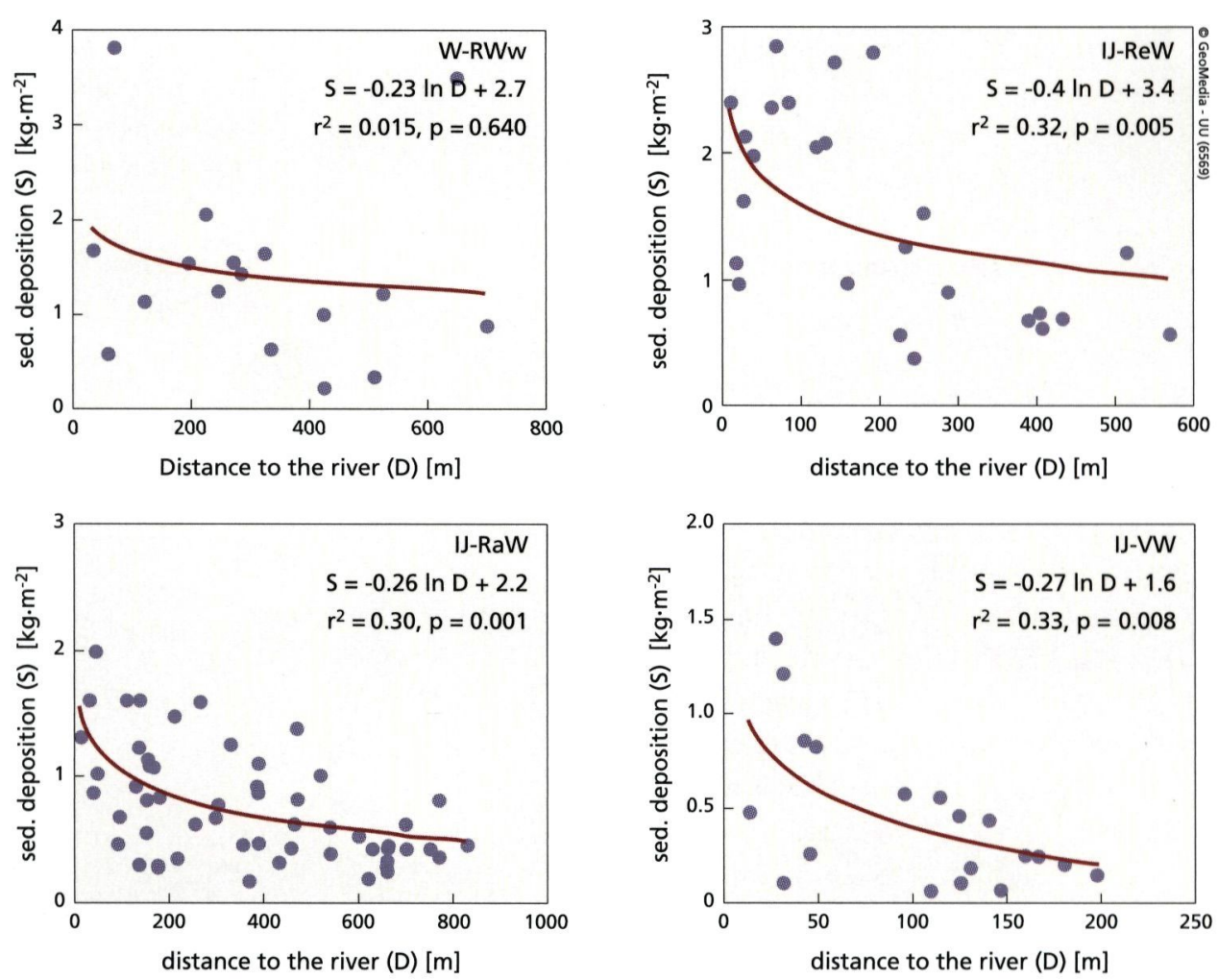
floodplain do not. The significant relation for the W-ADW has nevertheless the same reason as the trend with distance to the river we mentioned earlier. The lower parts in the southeast of the W-ADW floodplain are inundated by water that enters the floodplain in early stages of peak discharges. The higher parts are only inundated when the river water overtops the minor embankment. Hence, once more, there appears to be a division between floodplains with and without protection against lowmagnitude floods. The latter experience a significant decrease of sedimentation with increasing floodplain elevation and the former do not.

There may also be a morphological reason for this difference. The topographical variation in the natural and unlevelled IJssel River floodplains is considerably higher than in the levelled Waal River floodplains. For instance, about $70 \%$ of the sample points in the W-BW and W-ADW floodplain lie within a vertical range of one meter (Fig. 7). The combination of a narrow elevation range with strong short-range variation in sediment deposition (Asselman \& Middelkoop, 1995) may lead to weak or insignificant correlations. In the IJ-RaW and IJ-ReW floodplain, on the contrary, the elevation range is about $2 \mathrm{~m}$ (Fig. 7). This elevation range results in weak but significant correlations between floodplain elevation and sedimentation amounts in the IJssel River. Larger elevation ranges lead to even stronger correlations, as Keesstra (2006) showed. Despite considerable short-range variation in sediment deposition, she found a significant $\left(r^{2}=0.44, p<0.01\right)$ decrease of sedimentation over a $4 \mathrm{~m}$ increase in elevation for the terraced floodplains of the Dragonja River (southwest Slovenia). Lecce \& Pavlowsky (2001) confirm this using evidence from an opposite situation: smaller elevation ranges lead to less variation in sediment deposition. They found that the differences in sedimentation rates in lower areas $\left(1.1-1.5 \mathrm{~cm} \cdot \mathrm{y}^{-1}\right)$ of the Blue River floodplain (Wisconsin, USA) and its higher elevated terraces $\left(0.7-0.85 \mathrm{~cm} \cdot \mathrm{y}^{-1}\right)$ had drastically decreased after the creation of one nearly continuous floodplain area. This shows that also the magnitude of topographical variation relative to the shortrange spatial variation in sediment deposition influences spatial trends.
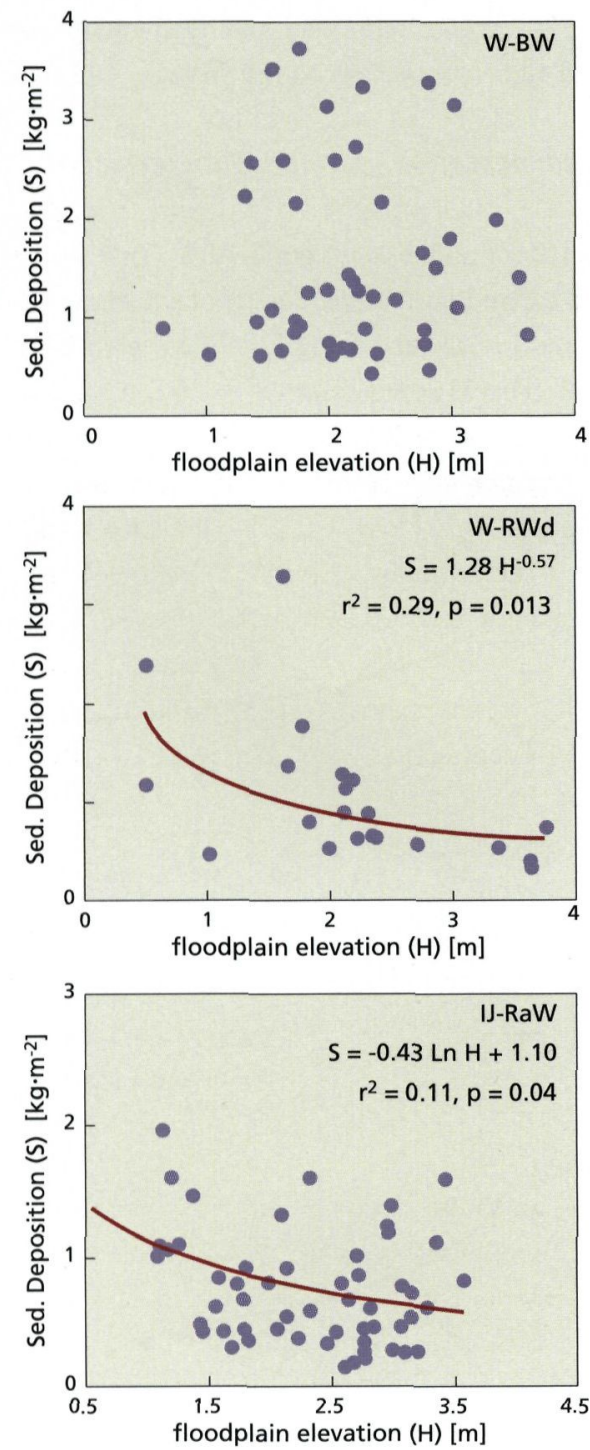
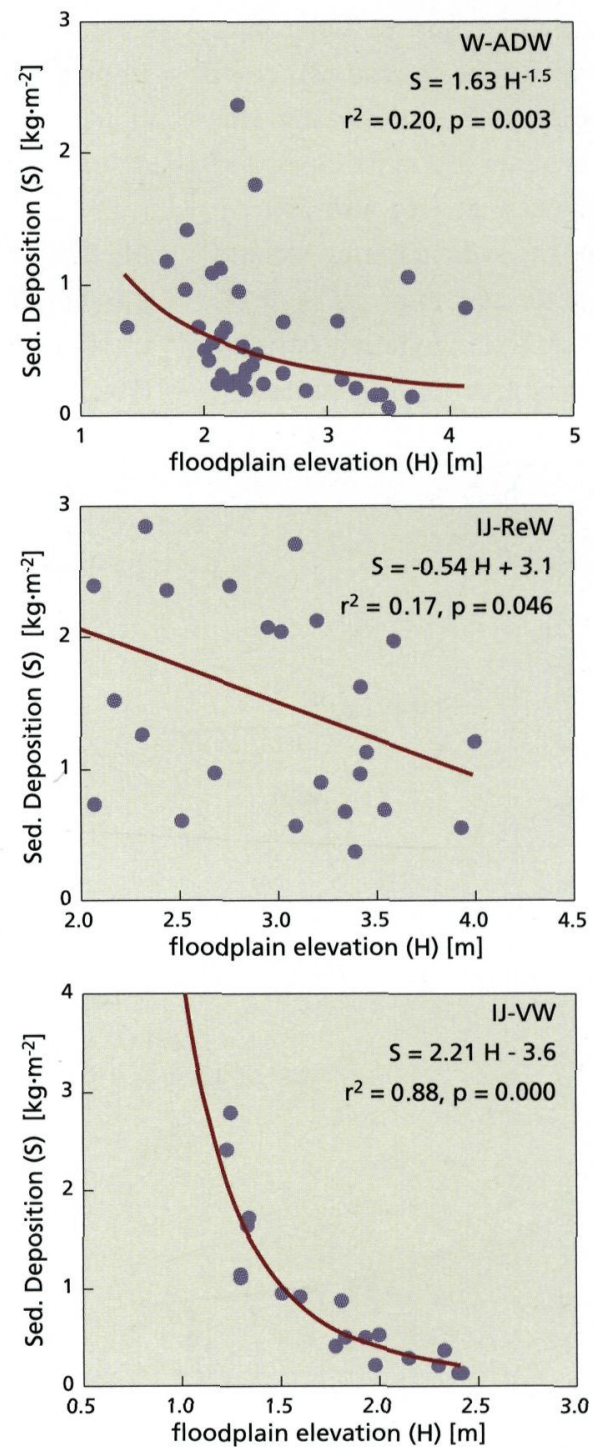

Fig. 7. Relation between floodplain elevation and sedimentation amount for two floodplains with minor embankments ( $W$-BW and $W$ $A D W$ ) and four floodplains without protection against low-magnitude floods (W-RWd, IJ-ReW, W-RaW and $I J-V W)$. 


\section{Conclusions and implications}

There are clear spatial differences in deposition and sediment characteristics between the floodplains along the human influenced Waal and less influenced IJssel River. These differences become manifest at two spatial scales: at the scale of the river branches and at the scale of their individual floodplain sections.

At the scale of the river branch, we could relate differences in sedimentation amounts, grain size distribution, and downstream exhaustion of suspended matter to morphological and hydrological variables. The relatively narrow embanked floodplains along the Waal River results in a major conveyance of sediment over the floodplains, where low flow velocities lead to deposition of predominantly fine particles. In contrast, the IJssel River floodplains experience less sediment conveyance during peak flows because its smaller discharge of sediment and water are distributed over much wider floodplains. Yet, this results in a high trapping efficiency of the IJssel River branch, resulting in a downstream exhaustion of the relatively little amount of sediment that is available for deposition. Because the high degree of meandering leads to convective transport of sand to the floodplains, IJssel River floodplains also trap significantly coarser sediments.

At the scale of the individual floodplain sections, we have confirmed a number of trends for the IJssel River that have been reported in literature for smaller rivers and the Waal River. In general, sedimentation amounts decrease with increasing distance to the river and increasing floodplain elevation. Yet, exceptions to these trends show that topographical variables, such as distance to the river and floodplain elevation often do not suffice to describe the pattern in more complex situations. For instance, there may be secondary sources of sediment in addition to the river channel itself, or complex hydrodynamic patterns at the onset of inundation. Furthermore, the presence of protection against low-magnitude flooding such as minor embankments and natural levees may drastically reduce the amount of spatial variation in floodplain deposits. It appears that this reduction increases with increasing height of the flood protection.

The comparison of these findings at the two scales shows that situation for sediment-trapping capabilities for individual floodplains reverses at the scale of the river branch. The floodprotected Waal River floodplains trap a large part of the sediment influx, but only a small part of the total sediment transport through the river branch during peak discharges. Individual IJssel River floodplains without minor embankments experience less sediment trapping. Yet, because the total surface of the floodplains is large relative to the sediment and water discharge of the river branch, conveyance losses are considerable and even lead to downstream exhaustion of suspended matter. This shows that both the individual floodplain and the river branch scale have to be taken into account when explaining sediment budgets for lowland rivers.
We summarise the implications of these findings as follows:

- At the scale of the river branch, morphological and hydrological parameters explain a major part of the variation in floodplain deposition. This means that measuring these parameters at this scale already gives considerable insight in the process, amounts and spatial patterns of floodplain deposition. Measuring these relatively straightforward parameters could also help to give a first approximation of a sediment budget for a river branch.

- At the scale of the floodplain, simple one-dimensional/ bivariate relations may not adequately describe the spatial pattern of contemporary floodplain deposition. Larger floodplains and/or floodplains with more complex topography and hydrodynamics during inundations may exhibit different relations than those generally reported in literature. In those cases floodplain deposition models could be of help, provided that their spatial resolution and the hydrodynamic input data are detailed enough. Yet, it is paradoxical that we still have to rely on empirical data on contemporary floodplain deposition to calibrate these models and to point out model flaws.

\section{Acknowledgements}

We kindly thank Bart Makaske and Gilbert Maas (Alterra, Wageningen University and Research Centre, Wageningen, the Netherlands) for collecting and providing the sediment traps from the W-ReW, W-RWw and IJ-VW floodplains. We also thank Diane Heemsbergen, Petra van Vliet, Sander Wijnhoven, Leo Thonon, Dick Middelkoop, Peter Burrough, Boris Nolte, Karen Winkelman, Menno Straatsma and Koos Jan Niesink for their valuable help in placing and collecting the sediment traps in the other floodplains. Koos Jan Niesink and Saskia Keesstra subsequently collected the sediment from the traps. Roel van Elsas (Mineral Separation Laboratory, Vrije Universiteit, Amsterdam, the Netherlands) helped to homogenise the retrieved sediment. Ton Warmenhoven, Marieke van Duin and Kees Klawer (Physical-Geographical Laboratory, Universiteit Utrecht) carried out the laboratory (grain size and heavy metal) analyses. Susan Marriott (University of the West of England, Bristol, UK) and Annette Doomen (Kiwa Water Research, Nieuwegein, the Netherlands) commented on an earlier version of the article. Harmony Folz provided access to some of the scientific literature cited.

\section{References}

Asselman, N.E.M. \& Middelkoop, H., 1995. Floodplain sedimentation: quantities, patterns and processes. Earth Surface Processes and Landforms 20: 481-499. Asselman, N.E.M. \& Middelkoop, H., 1998. Temporal variability of contemporary floodplain sedimentation in the Rhine-Meuse delta, the Netherlands. Earth Surface Processes and Landforms 23: 595-609. 
Asselman, N.E.M., Middelkoop, H. \& Van Dijk, P.M., 2003. The impact of changes in climate and land use on soil erosion, transport and deposition of suspended sediment in the River Rhine. Hydrological Processes 17: 32253244.

Asselman, N.E.M. \& Van Wijngaarden, M., 2002. Development and application of a 1D floodplain sedimentation model for the River Rhine in the Netherlands. Journal of Hydrology 268: 127-142.

Bathurst, J.C., Benson, I.A., Valentine, E.M. \& Nalluri, C., 2002. Overbank sediment deposition patterns for straight and meandering flume channels. Earth Surface Processes and Landforms 27: 659-665.

Brown, A.G., 1985. Traditional and multivariate techniques in the interpretation of floodplain sediment grain size variations. Earth Surface Processes and Landforms 10: 281-291.

Droppo, I.G., 2003. A new definition of suspended sediment: implications for the measurement and prediction of sediment transport. IAHS Publication 283: 3-12.

Droppo, I.G., Leppard, G.G., Flannigan, D.T. \& Liss, S.N., 1997. The freshwater floc: a functional relationship of water and organic and inorganic floc constituents affecting suspended sediment properties. Water, Air and Soil Pollution 99: 43-54.

Droppo, I.G., Walling, D.E. \& Ongley, E.D., 2000. The influence of floc size, density and porosity on sediment and contaminant transport. IAHS Publication 263: 141-147.

Foster, J.M., Thoms, M.C. \& Parsons, M., 2002. Using multivariate statistical techniques to interpret patterns of flood plain sedimentation. IAHS Publication 276: 451-461.

Gomez, B., Phillips, D., Magilligan, F.J. \& James, L.A., 1997. Floodplain sedimentation and sensitivity: summer 1993 flood, Upper Mississippi Valley. Earth Surface Processes and Landforms 22: 923-936.

Guccione, M.J., 1993. Grain-size distribution of overbank sediment and its use to locate channel positions. Special Publication of the International Association of Sedimentologists 17: 185-194.

$\mathrm{He}$, Q. \& Walling, D.E., 1997. Spatial variability of the particle size composition of overbank floodplain deposits. Water, Air and Soil Pollution 99: 71-80.

He, Q. \& Walling, D.E., 1998: An investigation of the spatial variability of the grain size composition of floodplain sediments. Hydrological Processes 12: 1079-1084.

Hren, M.T, Chamberlain, C.P. \& Magilligan, F.J., 2001. A combined flood surface and geochemical analysis of metal fluxes in a historically mined region: a case study from the New World Mining District, Montana. Environmental Geology 40: 1334-1346

Hudson-Edwards, K.A., Macklin, M.G. \& Taylor, M.P., 1999. 2000 years of sediment-borne heavy metal storage in the Yorkshire Ouse basin, NE England, UK. Hydrological Processes 13: 1087-1102.

Hudson, P.F. \& Heitmuller, F.T., 2003. Local- and watershed-scale controls on the spatial variability of natural levee deposits in a large fine-grained floodplain: Lower Pánuco Basin, Mexico. Geomorphology 56: 255-269.

Keesstra, S.D., 2006. The effects of natural reforestation on the hydrology, river morphology and sediment budget of the Dragonja River, SW Slovenia. PhD thesis, Vrije Universiteit (Amsterdam, the Netherlands): $187 \mathrm{pp}$.

Kesel, R.H, Dunne, K.C., McDonald, R.C., Allison, K.R. \& Spicer, B.E., 1974. Lateral erosion of overbank deposition on the Mississippi River in Louisiana, caused by 1973 flooding. Geology 2: 461-464.
Lambert, C.P. \& Walling, D.E., 1987. Floodplain sedimentation: a preliminary investigation of contemporary deposition within the lower reaches of the River Culm, Devon, UK. Geografiska Annaler 69A: 393-404.

Lecce, S.A., 1997. Spatial patterns of historical overbank sedimentation and floodplain evolution, Blue River, Wisconsin. Geomorphology 18: 265-277.

Lecce, S.A. \& Pavlowsky, R.T., 1997. Storage of mining-related zinc in floodplain sediments, Blue River, Wisconsin. Physical Geography 18: 424-439.

Lecce, S.A. \& Pavlowsky, R.T., 2001. Use of mining-contaminated sediment tracers to investigate the timing and rates of historical floodplain sedimentation. Geomorphology 38: 85-108.

Lecce, S.A. \& Pavlowsky, R.T., 2004. Spatial and temporal variations in the grain-size characteristics of historical flood plain deposits, Blue River, Wisconsin, USA. Geomorphology 61: 361-371.

Leenaers, H. \& Rang, M.C., 1989. Metal dispersal in the fluvial system of the River Geul: The role of discharge, distance to the source, and floodplain geometry. IAHS Publication 184: 47-55.

Maas, G.J., Makaske, B., Hommel, P.W.F.M., Nijhof, B.S.J. \& Wolfert, H.P., 2003. Verstoring en successie: Rivierdynamiek en stroomdalvegetaties in de uiterwaarden van de Rijntakken. Alterra-rapport 759, Wageningen University \& Research Centre (Wageningen, the Netherlands): $100 \mathrm{pp}$.

Marriott, S., 1992. Textural analysis and modelling of a flood deposit: River Severn, U.K.. Earth Surface Processes and Landforms 17: 687-697.

Mertes, L.A., 1994. Rates of flood-plain sedimentation on the central Amazon River: Geology 22: 171-174.

Middelkoop, H., 2000. Heavy-metal pollution of the river Rhine and Meuse floodplains in the Netherlands. Netherlands Journal of Geosciences 79: 411-428.

Middelkoop, H., 2002. Reconstructing floodplain sedimentation rates from heavy metal profiles by inverse modelling. Hydrological Processes 16: 47-64.

Nanson, G.C. \& Croke, J.C., 2002. Emerging issues in flood plain research. IAHS Publication 276: 271-278.

Nicholas, A.P. \& Walling, D.E., 1997. Modelling flood hydraulics and overbank deposition on river floodplains. Earth Surface Processes and Landforms 22: 59-77.

Simm, D.J. \& Walling, D.E., 1998. Lateral variability of overbank sedimentation on a Devon flood plain. Hydrological Sciences Journal 43: 715-732.

Sweet, R.J., Nicholas, A.P., Walling, D.E. \& Fang, X., 2003. Morphological controls on medium-term sedimentation rates on British lowland river floodplains. Hydrobiologia 494: 177-183.

Taylor, M.P., 1996. The variability of heavy metals in floodplain sediments: a case study from mid Wales. Catena 28: 71-87.

Ten Brinke, W., 2004. De beteugelde rivier: Bovenrijn, Waal, Pannerdensch Kanaal, Nederrijn-Lek en IJssel in vorm. Veen Magazines (Diemen, the Netherlands): $228 \mathrm{pp}$

Ten Brinke, W.B.M., Schoor, M.M., Sorber, A.M. \& Berendsen, H.J.A., 1998. 0verbank sand deposition in relation to transport volumes during largemagnitude floods in the Dutch sand-bed River Rhine system. Earth Surface Processes and Landforms 23: 809-824.

Thoms, M.C., Foster, J.M. \& Gawne, B., 2000. Flood-plain sedimentation in a dryland river: the River Murray, Australia. IAHS Publication 263: 227-236.

Thonon, I., 2006. Deposition of sediment and associated heavy metals on floodplains. Netherlands Geographical Studies 337, Koninklijk Nederlands Aardrijkskundig Genootschap / Faculteit Geowetenschappen, Universiteit Utrecht (Utrecht, the Netherlands): 174 pp. 
Thonon, I., Roberti, J.R., Middelkoop, H., Van der Perk, M. \& Burrough, P.A., 2005. In situ measurements of sediment settling characteristics in floodplains using a LISST-ST. Earth Surface Processes and Landforms 30: 1327-1343.

Van der Lee, G.E.M, Olde Venterink, H. \& Asselman, N.E.M., 2004. Nutrient retention in floodplains of the Rhine distributaries in the Netherlands. River Research and Applications 20: 315-325.

V\&W, 2005. Waterbase; www.waterbase.nl. Ministerie van Verkeer \& Waterstaat (The Hague, the Netherlands).

Walling, D.E., 1999. Invited lecture: river floodplains as sediment sinks. In: Jayawardena, A.W., Lee, J.H.W. \& Wang, Z.Y. (eds): River sedimentation Theory and applications. Balkema (Rotterdam, the Netherlands).

Walling, D.E., Fang, D., Nicholas, A.P. \& Sweet, R.J., 2004. The grain size characteristics of overbank deposits on the flood plains of British lowland rivers. IAHS Publication 288: 226-234.

Walling, D.E. \& He, Q., 1998. The spatial variability of overbank sedimentation on river floodplains. Geomorphology 24: 209-223.

Walling, D.E. \& Owens, P.N., 2003. The role of overbank floodplain sedimentation in catchment contaminant budgets. Hydrobiologia 494: 83-91.

Walling, D.E., Owens, P.N. \& Leeks, G.J.L., 1998. Erratum to "The characteristics of overbank deposits associated with a major flood event in the catchment of the River Ouse, Yorkshire, UK'. Catena 32: 309-331.

Wijnhoven, S., Thonon, I., Van der Velde, G., Leuven, R.S.E.W., Zorn, M.I., Eijsackers, H.J.P. \& Smits, A.J.M., 2006. The impact of bioturbation by small mammals on heavy metal redistribution in an embanked floodplain of the river Rhine. Water, Air, \& Soil Pollution 177: 183-210.

Wyżga, B., 1999. Estimating mean flow velocity in channel and floodplain areas and its use for explaining the pattern of overbank deposition and floodplain retention. Geomorphology 28: 218-297. 